\title{
AN INTERVIEW IN ZION The Life-History of a Jamaican Rastafarian in Shashemene, Ethiopia
}

by Giulia Bonacci

On September 27, 2003, I sat with Rastafarian Junior Dan ${ }^{1}$ on the top of his unfinished house in the Jamaica sefer (the Jamaican neighborhood) on the outskirts of Shashemene, a southern Ethiopian market town. I solicited him for an interview as I was conducting research on the social history of the Rastafari repatriation to Ethiopia and their settlement on the "Shashemene land grant." ${ }^{2}$ I had been in Shashemene for almost a year and had by then a fairly good understanding of the history and of the contemporary dynamics of the settlement.

In 1950, five gashas - or 200 hectares - of fertile land in the periphery of Shashemene were granted by Emperor Haile Selassie to the members of the Ethiopian World Federation who had defended Ethiopia during the Italian war (1935-1941). As a token of appreciation for their moral and financial support, the "black people of the world" were invited to come to Ethiopia, to settle, and to contribute to the country's development. The Ethiopian World Federation (EWF) was founded on August 25, 1937, in New York, on order of the Emperor by Melaku E. Beyen, an Ethiopian who had previously studied in the United States and was married to an African American lady. The EWF's objective was to agitate public opinion about the cause of Ethiopia, to raise funds for the war effort, and to contribute to Pan African solidarity. The Shashemene land grant represented a tangible territory with which Back-to-Africa aspirations could identify. A few Caribbean and African American settlers arrived during the 1950s and 1960s, but it is Jamaican Rastafarians who eventually peopled Shashemene's settlement. Coming directly from Jamaica since 1968, their arrivals slowed down during the years of the Derg (1974-1991) and resumed with the change of regime in 1991. Reflecting the ongoing internationalization of the Rastafari movement, Rastafarians poured in from many different countries and backgrounds. Today, the Rastafarian community of Shashemene, about 600 men, women, and children of fifteen nationalities, is unique in Africa in its longevity and its diversity.

Of the sixty recorded interviews conducted during my research, Junior Dan's is particularly interesting. A fluid and balanced exercise in oral history, Junior Dan's interview is fairly representative of a "generation" of settlers, young men-and a few women-from the Rastafari organization the Twelve Tribes of Israel who came to settle in Shashemene since 1972. His life-history illustrates how he became a Rastafarian, and particularly a member of the Twelve Tribes of Israel, how he left Jamaica, as well as the vicissitudes of living in Ethiopia. As such, it unveils the social experience of repatriation to Shashemene and life in Ethiopia in the past thirty years. The voices of the returnees represent a methodological tool particularly important for historical research. Once collected, discussed, 
and analyzed, these voices offer unique insights into the little-known history of African American and Caribbean settlers in Ethiopia. Furthermore, they contribute to the shaping of the history of the Rastafari movement, determined by the role played by its organizations and their mobilization towards the Shashemene settlement. They offer yet another version of the major social and political changes that swept Ethiopia since the 1970s. Eventually, these voices articulate the challenges and the significance of the Pan African relationship as experienced not by the Pan African elites but in the everyday interactions of "small people" in a particular location.

Oral history has a particular rhythm, shaped by intonation, a particular vocabulary and grammar, and is accompanied by the language of the eyes, hands, and body. Publishing oral history raises a number of issues and it is an uneasy task to pay tribute to the power conveyed by the sound once it is fixed on paper. While Jamaican patois has been honored through many literary works, it remains little known in academic circles. For the sake of clarity, the life-history of Junior Dan has been slightly edited. However, peculiarities of his voice have been left in the text. An unorthodox use of English, it has a poetic strength and conveys both a culture and a context that contribute to the shaping of contemporary identities. Repetitions, particular structure of sentences, creative grammar and pronunciation-if puzzling to the readers-are to be taken as Jamaica's contribution to the rich diversity of English spoken around the world.

JUNIOR DAN: I was born in October 1949, in St. Catherine, Jamaica, and was taken away from St. Catherine to Kingston so I was brought up in Kingston, between St. Andrews and Trench Town. ${ }^{3}$ I went to different different school. First, I gone to Prep school in Jones Town and after to primary school in Kingston, Kingston Primary Prep as they call it. From there I attend high school in St. Andrew, and after I finish high school I went to college but never stayed in college. After, I went to an engineering school called Morris and Civil engineering, on Hagley Park road. While in the school we use to go onto the fields to do different different severing and planning. After I left that school I joined the organization Twelve Tribes of Israel, this was in $1965 .{ }^{4}$

My family, they were like Church of God people, and I was baptized when I was about fifteen, sixteen. I wasn't approving to the kind of things going on in the church, like the pastor is going with the church sister and all kind of confusion so I left that. Then I start seeking for God himself. I know there's a God, I know we must pray to God and God business is serious and all of that, but what the Church was showing me, I wasn't accepting that as the real thing. So I start searching and then it was in a vision first that I see His Majesty. ${ }^{5}$

Then after the vision I used to hang out with these bredrens and we used to stay out, we used to gather at this place, and keep the Ethiopian Sabbath on Wednesdays and Thursday no, Fridays, but we never know the particular day, we never had it right cause we used to observe Tuesday and Friday instead of Wednesday. ${ }^{6}$ One Tuesday I was having like a fast day, and this Tuesday I have seen a vision in this kind. I wasn't asleep but I 
know it was a vision, I was like in a trance. The day was like-you know a tornado? Like a whirlwind starting from a small point and a cloud was going like that. So it get bigger and we start seeing like two feet and form out to a belly until we see it was a clear picture of His Majesty dressed in a field Marshall with that hat.

All this time I was going to school, I was like fifteen and this bredren-first he left school because him started dreadlock—and he came to my house and say: "you know that Selassie I is God?" and I say yeah, tell me more about that. And him start explaining to me: "well Selassie is the King of Africa. There was a man call Leonard Howell, he started about when the King is crowned in Ethiopia, Black people should look for redemption." And this guy my schoolmate was telling me all of this. But the most thing he tried is what I can tell you: Haile Selassie is the almighty God. Because he was showing me certain Bible scriptures as well and I was convinced is that I went home from this place and told my mum, "Haile Selassie is God, I don't want no more pork feet, and I don't want to do this and I don't want to do that," and eventually I was thrown out of my mum's place because of that. My mum told me I must go and live with these people that is Haile Selassie followers. I left there, and start live with my friends and all over the places and my mum start crying for myself. Eventually I went back, when I was seventeen. This time I was dreadlocks, fully Rasta. That is when [a] bredren told me there's a place in Trench Town where they are having this function that is called the Twelve Tribes of Israel and this was 1965.

BONACCI: Did you know about the people who had been to Africa on a mission?7

JUNIOR DAN: No, I hadn't known about all of this. When I start getting a little bit of this is when I was in the organ [Twelve Tribes of Israel], because when I was in the organ my mum sent me from St. Andrews which is uptown to Jones Town to my Grand-Ma to deliver a message. While I was going on my way, there is this place in Kingston which is called Tarrington Bridge, it's between Crossroads and Kingston, and there is this big place called race course where you have rallies, where a lot of people rally like and everyone was heading in that direction. I got off the bus and started following the people instead of going where my mum sent me. Eventually I end up in this race course where they are having this big Rasta rally.

These men had just returned from Ethiopia, which is Alvaranga Fil [Filmore Alavaranga], Dougy [Douglas Mack], Mortimo Planno, and all these men with a mission to His Majesty. ${ }^{8}$ And these men were making the report to the people, especially to the Rasta nation of Jamaica, and they were playing a tape, an Amharic tape which His Majesty was on, talking about Jesus Christ and Ethiopia. However, he made a statement that was appealing to me and that disturbed my whole life for about three months. What His Majesty was saying is that he himself is also saved by the blood of Jesus Christ, and all Christians should look to Christ for their redemption. And this really disturbed me, because I was licking out against Jesus Christ, I was saying he is a sheep, Jesus Christ was money and was all kind of illusions-which I was the one who was illusioned, not Christ.

After I left the rally I went where my mum send me and went to deliver the message and immediately I was out of the house again, and I was going to Trench Town, going back to Kingston 12, 7 Davis Lane where the HQ [headquarters] of the Twelve Tribes was, I was going straight there to see the Prophet cause he was living there, because I was disturbed 
and wanted some clearance in my head. ${ }^{9}$ I went to him and say I just found out that men come from Ethiopia and were keeping this rally and dis and dat. Him tell me: "Look here, that is why we always say 'Greetings in the name of our Lord and Savior Jesus Christ,' because His Majesty 'a reveal himself that way, all a reveal himself through His Majesty because he is the only person in our time having all these titles fit-in the Bible that God use to remind of the coming of God."

I left him and I was still a bit confused because I couldn't sort out what he had said to me, I never understand everything. It took me three months to understand clearly that all people-regardless of what walk of life they come from, regardless of what nation, what is their belief, how much dem is Rasta-have and need to understand and believe in Jesus Christ as their Savior because in fact and in truth it's only one way and he say, "I am the way and the truth and the life, no one comes to follow but my way." As a result he could give his life for humanity, nation, and people. That is why Jesus Christ went to preach to everyone.

After I understand that, I start getting more deep in the Bible, and start reading avidly now, not just the Bible but everything I could put my hands on especially hard literature, not just fictions, cause I was reading fiction as well. But what I come start to realize is that most of the ambition that I had, I wanted to be in Ethiopia, and we keep attending function at the organ.

BONACCI: Did you become a member after the meeting with Brother Gad?

JUNIOR DAN: I was already there, but we just function EWF. ${ }^{10}$ And that was when it happened. It was about 1967, something like that. Just before the organization set up, I went away in the hills this time with the bredrens and start dreadlocks, real dreadlocks now, Congo dread not wearing no clothes in term of Babylon clothes and wearing like sand pats and all those things. For a good three years and the organization set up, when I come down the hills I see it set up and went back to the hills. All this time I should have been in college you know cause at the same time I enter college but I leave because of the faith and teacher can't teach me nothing and I man bigger than teacher and all dem bullshit. Eventually my mum start fussing cause it's a good three, four years she never see me, and I getting sounds from people who meet her and I went to her and start staying with her. About a year, and start approach the time when Gadman start say people must get their passport seriously ready because people gonna travel—but I had my passport already. When it turned $1976 \ldots$

BONACCI: But something happened here which is the Ethiopian revolution. How did that impact the people over there?

JUNIOR DAN: In Jamaica? Well as far as I was concerned, all of that didn't touch me none at all. Because I was so strong faith and deep rooted in Ethiopia, the King of Kings, although it was affecting other people, because people start cut off dem dread and leave the faith. Me was a yout' just vibrant in the faith, so den I come into Ethiopia. And the organization started to send us. At the same time you had some people leaving from Ethiopia to come back to Jamaica as well. ${ }^{11}$ Because a lot of things was going on in Ethiopia as well, the 
same Ethiopian revolution, and people were not going to stay to see what happen after, so people was coming out. By the time we got here in August of 1976, you had a handful of people left here. When we came here now ... first to begin with, when we came to Addis Ababa, we had a small son with us, and he was like six, seven months old.

BONACCI: You came with other bredrens at the same time?

JUNIOR DAN: No, I came alone with my baby son, and we booked ourselves in the Taitu hotel, not the Taitu, the Dahab Hotel. It was advised that it was a good place. But I can say that Dahab was nothing more than a toilet hole.

BONACCI: The organization financed the plane ticket?

JUNIOR DAN: That's what I am coming back to. Before I left Jamaica, being a member of the organization, we were called up in a meeting and what the Prophet ask us in the executive body is if we are ready to go to Ethiopia. ${ }^{12}$ And we say yes. "Are you ready to leave your wife and your kids?" Because I had a woman and a baby boy. "Are you ready to leave your mum and everything you have?" Me say yes. "So you must bring forward your passport so you can get visa." They are the one who paid the fare. My passport was already with the Prophet. The Prophet brought it to me and say bredren this passport just expired you need to get it fixed because you are going to need it now. Immediately, as he said that to me and I took it from him, one of the executive bredren, a Asher bredren, took it from me and say, "well I can do this for you."13 I got my passport in a day after that. It was criss [cool]. They took it to New York, put the visa in it, fixed my fare, and they send me off with my son. I myself found my son fare, which was something like 5,000 JA $\$$ then.

BONACCI: The woman could not come?

JUNIOR DAN: No, it wasn't her time, not her turn to come. People had their turn according to when they joined the organization. So they were sending me and after that I was promised that my wife would come. I wanted my son to travel with me, I wasn't leaving him. So I brought him. We came here.

BONACCI: Somebody was there to welcome you at the airport in Addis Ababa?

JUNIOR DAN: None at all. I came on my own and was there on my own. Well, when I came to the airport I had a good flight and landing but everything was different. I hear man speaking around me, the land look different, the people look different. Cause when I came people never used to be dressed up in clothes like this, most of the people dress in their national dress, whether man or woman. With a gabi around them. I asked direction from airport and we got to Piazza, and we book ourself in this hotel call Dahab. It was filthy, people there were nasty, like spitting in the face basin, I was disgusted. I stayed for three days and while I was there, you had different Ethiopians coming to see me about the land, and people who came here already and they could do this and that and eventually 
I trust one of the bredren and gave him $\$ 300$ so that he make change for me cause I had feeling like the place-it was raining time, like now, place was so dumpy and outside was so cold and nasty and all I did was getting my room speak and span and to stay there. So I wanted someone to go and get it for me. So I was paying this boy cause he had come tell me about [one of our bredren in Shashemene], how he paid his school fee and how they got friends and he had me trust him. I start go buy bread for the yout' and milk for the yout' eventually he start telling me when I leave he wants to come to Shashemene with me so I say yeah I can trust you. So I say look here in the morning when you come cause I want to go the day after tomorrow to Shashemene, I want you to get me some change from the bank. So I gonna give you this money and you go. I gave him a criss pair of brown shoes that I had, I gave him twenty-five birr for his pocket money and five birr out of the twenty-five of the bus fare to go to Shashemene, and twenty-five was like a hundred birr now or maybe more. He took the shoes, put it on, took the twenty-five birr, went away to change my dollars and he didn't came back. I tell you that piece of shit! When he took the money and he didn't come back when he should have, which is the same day, night come and maybe he come back next day. Just as well I still had some loose birr from the twenty-five birr that I had so that I could pay from the hotel to the bus station so that I could get here well, put everything together, that was the third day.

BONACCI: That money you came with, it was raised with a dance?

JUNIOR DAN: Yes, this was my first and only dance until today in my life. I never kept another dance. ${ }^{14}$ There was a send off dance, and I came with a lot of money, maybe I came with I can't remember exactly now, but I sure I came with like at least 5,000 JA\$ dollars at that time, or more which could get me a nice $c^{\prime} e k^{\prime} a$ [mud] house even, like that or maybe bigger. When I came here I couldn't talk. I didn't know anything so the people I was staying with made sure I finish it. Anyway ... I going too fast.

When I left Addis Ababa, I went on the bus and I had my bags and my son. Immediately the bus station was a confusion. I got from the hotel to the bus station. There was so much people buzzing about, and everything was like different from what I know, the language, the people look different, everything however there was all these big buses waiting for people to take them to different destinations and they showed me the Shashemene one. I got on to the Shashemene one. When the bus filled up and I told to myself "oh my God, this is a nightmare," I mean people having flied and nose knot and all kind of stuff on them, which normally no people would go about that way. But people was like that. When the bus start driving, no one would allow the bus to be open, the windows-it would be the stink, it give you want to vomit, at least those things happened to me, tried to shield up my yout' and open the window but although I couldn't open it even though I pull it open and people say “oohhh!!” All kind of things. I couldn't understand and had to close it. We got to Shashemene.

BONACCI: Up to town?

JUNIOR DAN: No. Pass the old settlement ${ }^{15}$ and got to where they play football, and the bredren that was living there I saw him there attending a lot of sheep and goats that he 
had then and I start saying to the people on the bus stop, stop, I want to get off, people were laughing at me fucking faranj [foreigner]. The bus stop right at the check point, start get my things out the yout' off and-at the time any bus that would stop people would be there and stare to see who is coming out-even now. The bredren was standing and looking and when I saw him I start waving at him and he start coming to me. We start hugging and kissing at each other and him say "bwoy you take the little yout" - "which part a de sekklement?" [where is the settlement?] "Dis part"—-me start realize me passed it and we took up the bags and start walking. My son start walking. Immediately we reach the settlement and the bredren start introducing the people to me like Junior Dan, come so! I put my bags away by a next bredren place. The reggae beat was still pumping in my vein and I had a whol' heap of cassette and player and just take it out, line it out and music I was talking like-I got to the settlement at five o'clock in the evening and maybe it was getting six o'clock and start getting dark. By time we get to set up the tape it was seven o'clock then. We start talking about Jamaica, the organ, and Rasta and talk the whole night without a blink, talking and smoking and eating and drinking ... The next day I decide I want to see where the bredren dem live.

BONACCI: How many bredrens of the Twelve Tribes of Israel were arrived already?

JUNIOR DAN: Well, no more than eight, nine bredren was here when I got here. With one sister, a bredren wife, but she left. We meet and greet each other. From there I start see what is the prospect of making life here what you can do to work and make money and all of that. Then it was just c'aka [forest], you see those long grass, they grow tall so you can hide between them and it grow a lot in this place so you rub it and dick dick and lot of things running in between them. We used to love eat bird, make a slingshot and shoot birds, anything - that time people eat a lot of meat, everything is a piece of beef but sometimes is bom bom bom and two-three birds . . . I couldn't take what was here cause my expectation wasn't fulfilled at all. What I expect how Shashemene and Ethiopia generally stay? Weren't like that-a lot of flies.

BONACCI: What were you expecting?

JUNIOR DAN: Well let me try see if I can find the words . . . because I was coming from a modern world I was actually expecting Ethiopia to have proper toilets and proper sanitary convenience and people being hygienic and all of that. The place not being so bushy. My expectation was a bigger one, like maybe it should be more developed then and people would be more clean in their appearance but it weren't so. However, all the people we had stayed with we start being so disgusted about them daily and one of the things that start confuse me is we can't talk even if I want to get sweet I haffi ask someone to buy it for me. I didn't know how to say nothing! Just like a dumb man. That's how they got to exploit my money, tell me prices which thing never cost that.

One of the thing that I start develop early-cause I love girls you see, and I wanted to have a woman I could talk to, not just for sex or anything like that, and I never had me wife or sistren nothing so I decided I have to learn Amharic for myself. ${ }^{16}$ I start going to market in the daytime not buying, just walking from one place to the people see what they 
sell, until I start learning aydellem [it's not], eshi [OK], aye [no], and I would start writing on a piece of paper what I hear and would ask one what that mean and to buy that what I can say. Little by little I start I realize I accumulated a lot. I had so much words buzzing in my head I didn't know how to use them. But I could remember how to say things although afraid to say it. I continued till I start talking to people. One of the first thing I went for is sugar. Sukwar yefelligal (sic) [I want sugar] and the man ask sint [how much] and I just repeat sukwar yefelligal ... From that happen it brighten me up so much I could go and start using the language around all the things that was buzzing in my head until people say gobaz [brave]. In six months I was having a little conversation. When I start get familiar with the Amharic, I stop noticing all that was disgusting around me, flies sometimes I would sees someone 'pon the road and say "why you don't bathe?" All of us was doing that anyway. We notice that people around us start washing face in the morning and upgraded the whole village, it start transform, clothes started to get cleaner ...

BONACCI: You were still living by the same bredren at the time?

JUNIOR DAN: Yeah. About a year after that, no, nine months after that another bredren come back and say him want to give me his house. It has nothing like how it is now. It had an open front and I start make a closed house. You remember how they had the board? All in board.

BONACCI: It was his house?

JUNIOR DAN: It wasn't built by M. Brown, but it was build by this other man, who leave it to Salomon Wolfe but somehow all of them had left it and it was him who had rescued the house, fix it up, pay up the bills, and then now when I came into the place he gave me the place and I bought from him the furniture that he had, like beds and tables. He went to Addis he got a job at the United Nations. We still use the bed and I bought table and chairs, and after I start living the house and fix up the yard the house itself, nice it up, reinstall the house with logical wise, pay a whol' heap of money that they left over, light and meter. I lived there for quite some time maybe about eight years. Here they come now and say that it's their place and I have to leave the place. They put me in jail three times to leave the house because I had refused.

BONACCI: They appealed to the authorities and the police came to take you?

JUNIOR DAN: Yeah all of that. Went to jail three times and appealed two times to get out of jail. After I went to jail for the third time and I came out I forcefully went for the kebelle [local urban administration]. They came with guns and soldiers and put me out of the house. They took all my things out. I decided I go to town to rent a place and the bredren dem say "no man, you can't leave the sekklement [settlement]." And they put me in that place.

BONACCI: In the house where you were living for eight years there was a workshop? 
JUNIOR DAN: Yeah we made that! The combs and the coffee table and all those things, silk box, cupboards. We had to leave out of that place, and we had this piece here planting and that somewhere along the line we're gonna get some money to build on this place.

BONACCI: What did you plant?

JUNIOR DAN: Corn, potatoes, peas, vegetables, even until now, it's about the first year we haven't done it. On the seventh year I leave it to fast. This is the seventh year since I was planting that's why you see the bush, but every year I planted crops, if I'm not planting wheat I'm planting barley, potatoes, peas, vegetables, carrots, cabbages.

BONACCI: It wasn't fenced?

JUNIOR DAN: It was fenced. It has been fenced for very long time. This land has been fenced for the last twenty years, except I fenced it with barbwire.

BONACCI: There was a land division set up by the government?

JUNIOR DAN: It is so bad for memory-I know you people love dates.

BONACCI: Twenty years that means the land had been given to the people in 1983?

JUNIOR DAN: Look here-everything since we came here since the early times we had always been issuing land and taking away land away from us. When they actually gave land to individuals that you call a division which is true, which was the last time when Brother Gad come? You have that information? 1986. It was the same year when him was coming here we get the land. ${ }^{17}$ When they divided the land between us. Even himself came and say to us he loved how they give us the land individually but we don't take it we should go and take it. That was 1984. After that they came and do the land division. Each of us was given individually but what they did was to give one person on that side and one person on this side who divided the land between all of us that is on this side...

So each of us get that big big plot of land from the land that was given. And we still had more land cause you see from my corner there to that corner there I had gone that way, almost to the potato and the sweet potato here, but it was the Ethiopian construction company who came and decided to build all that land that you see they have here now. They wanted to put the Ethiopian construction on this land. Someone in the government, high up, told them is better to leave that land alone because it was given to Jamaicans. That land grant is canon, whatever is on there the Jamaicans are gonna get it eventually. And they left, took all their equipment and material and they had a lot of zinc shed even now one is still there. They took away their things and went away. Many years after these people came, is about a year ago now and I understand this place is now a vocational college, agricultural educational college, that's how I understanding things are going to be.

Here we are. I can say I had good times and bad. But even the bad times I had I consider them not bad at all. In all pioneer work, people have to build spearhead for the rest of the 
spear that has to come through. Because that is our pioneers works. I can truly say that we were pioneers for everyone that come here now. I have no regrets being here. Even though I don't have all the material things I would want, even the material comfort that I used to as a child growing up although we weren't rich, we weren't short of the things to make life comfortable. We weren't hungry, like denied schools because our parents couldn't afford it.

BONACCI: Tell me about the Derg years. You did woodwork and farming for subsistence?

JUNIOR DAN: Yeah, we used to sell our clothes, and money finished, I mean even fork and spoon and knife everything we had. When we finished that we were all dry we start doing farming more, but it weren't subsistent, so we had to find a way to make money, and we start to make woodwork, carpentry, combs, rock boats, tables, cupboards, beds, all kind of things. It went on until they took the wood shop from we that we used to find material easily and then we start going to other kind of place to get material until difficulty start came in where wood is concerned. We start getting visitors, people start concentrating, doing trade outside, like for example I was knitting craft, and I was selling a lot of craft into the West-hats, belts, platted things, hammocks - and start making money from there. That was my real profession, contracting, I do building contracting. Eventually we start-one of my fine lines is interior decorating with ceramics, art paper whatever. Here and there I start that kind of job as well and I start working between here and Addis Ababa and start making money. Until the trading stop outside and start concentrating more on my profession, and I'm working on that now.

BONACCI: During the Derg was there any pressure about His Majesty?

JUNIOR DAN: Yes, there was pressure. We couldn't talk anything about His Majesty, we couldn't display portraits of His Majesty, nothing where Haile Selassie and his government was concerned. You have to be totally conservative. Through those years, although we were publicly and openly declaring our faith and what we stand for, we weren't pressured in ways like individually by the government, we didn't get any molesting from them. They didn't disturbed us. I can say truthfully speaking the Derg government, where the Rasta community is concerned, is much better than this present government. Because immediately when they came to office [in 1991], they make a public statement on the radio that they are no brother or sisters of the Jamaican community. You know Meles [Zenawi] said that! Because Mengistu Haile Mariam made the statement before he left that he and the Jamaican people are brothers and sisters and truthfully we are blood brothers of Ethiopia and we are more Ethiopians than the Ethiopians themselves. Meles had gone that far. Even when he came to office he made that public statement saying that he and the Jamaican community is no brother and sister he is an Ethiopian and the rest of it. In the Derg regime no one ever disturbed or molest no one building a house let alone demolish part of it. This system have our houses demolished. For all of us. Even though we were building in Derg situation, and people were building, no one ever stopped them, even though we couldn't build openly because they say it is kilkil [forbidden], but if you 
do something, no one come and stop you and molest you. It's more drastic in this regime as far as we are concerned.

BONACCI: During the Derg you were never asked to become a member of political parties?

JUNIOR DAN: Us? None at all. We had never been even in Jamaica we had never voted. We had never been no government nothing like that. We left from being students, experience worker and from there we left Jamaica.

BONACCI: The fact that Prophet Gad came here around 1986, did that made any change in the community?

JUNIOR DAN: Yes, it had. I can say when Brother Gad came the last time, he had made a contribution to extend the HQ from his pocket. I think he had given $\$ 8,000$ US dollars, and other people make contribution on that money, and that why it extended the other side of the HQ. Just that made an impact. Apart from that he had nationalized a lot of things. I mean bredren and sistren from outside were coming here and trying to make contributions to different members to construct a house, dem times these people were giving contributions and some people use it to override other people. Like it's because of us why you have that place, maybe they would want to come in and occupy the place again. Gadman had known these thing and came and say well all those people who have those kind of contributions, he want to nationalize everything through the central fund, make it central fund for everyone so that not only certain people would get support but everyone. We did that.

BONACCI: You get support from outside?

JUNIOR DAN: Me? Well that time I was in Addis working and found that a bredren had left something for me to construct a house and how him do that although I was away working, they keep a meeting and him asking who is the person most need a house? And the bredren came together and say, Junior Dan. That is how the money was left for me. In fact and in truth I never used that money. I gave it back to the organization, nationalization. I was cut up with why they choose me. I'm not a puppet and I don't want no one to leave money I was going about it and for that the money was in the bank for a long time. When the government had came and took all of us to the Mekr bet [Town Hall] and decided to give us residence permit for who was here over the time that would be eligible, it was a whole emigration question for the Jamaicans that were in the country then. And they wanted to know who was legal from who was not.

BONACCI: That was during the Derg?

JUNIOR DAN: Yes. I think that's the baddest thing that happened to us as far as the Derg is concern. It wasn't bad but what they were doing first was sorting us out to give us credential so that we could be legal and recognized in the country. They ask all of us to come 
to the mekr bet and all of us who didn't have papers they took us to court and to the police station. They didn't lock up any one but that's the procedure. And pay some money. Some of us pay a hundred birr, some of us pay fifty and that was when I used that money to pay for me and my wife. The house was paying for us as members, so I used that money to pay for my wife as she wasn't a member then. Eventually I gave all that money back that was given to me as a contribution for the house to the House [Twelve Tribes of Israel]. I had taken no contribution. Apart from a bredren and sistren who came-I use to know them from before, like your Idren, and they might give you a hundred birr-whatever they gave you. Apart from that I didn't get no contribution, all you see I have here, every block, is all my sweat and blood, and my wife, everything we do is our own. Even this place I've been building and cost me so much money, it's all our efforts, me and my wife.

BONACCI: So from that time you got papers?

JUNIOR DAN: Yeah, they give us papers that go to immigration and all of us was sorted out and get residence permit.

BONACCI: Everybody could pay?

JUNIOR DAN: Some people could, some couldn't, but everyone had paid anyway because everyone was happy for it. It's just recent people start getting inappropriate with paying, and become unfinancial and not having their residence permit up to date and all of that, cause you have a lot of people here like that. That maybe started for about the last three, four years. That was long time ago.

BONACCI: What are the main changes you can see from the fall of the Derg [1991] to this next government?

JUNIOR DAN: One of the things I notice is that there is no law in the country and I also observe there's a lot of stealing from the top to the bottom, which wasn't like that before. It was there but not to that extent. There's a lot of development in term of construction, changing from mud huts to blocks. Unconditionally as well throughout the country. This country has drastically changed in that they have separated the ethnics and make them into separate groups of people instead of being one country united..$^{18}$

BONACCI: Within the community what are the main changes?

JUNIOR DAN: More development. The whole of the place, even the airfield they have ex amount of house there like they are relocating the people from one region to another, different houses, on this settlement in particular, cause you have the infrastructure of the new road coming into the settlement, the King's highway and that give the whole land mass a face lift and as a result of the new road you have new businesses both in town and the village and the surrounding. 
BONACCI: More and more people?

JUNIOR DAN: Constantly influx of people, foreigners as well as Ethiopians coming from different place coming to settle in the immediate part of the country. Shashemene? Constant influx of people coming in, from foreign, Rastafarians, and visitors, both coming to live or visit and go back, constant influx of Ethiopians as well, trying to occupy the land, cause their intention is to occupy a piece of the land with no intention of staying there but to sell back to Jamaican people or to the people coming to live.

BONACCI: When did you start building this house where we're sitting?

JUNIOR DAN: This was four years ago, August 2 [1999] we started the foundations, then we started building blocks, and for building the storey it was August 23.

BONACCI: In these four years, no problem?

JUNIOR DAN: No problem at all. Just at the time of completing the place they started demolish.

BONACCI: Why did they wait so long?

JUNIOR DAN: I think it was deliberately done by jealous people. I am sure I am making a lot of people feel bad. You see the fact that we are members of the Twelve Tribes of Israel and our Prophet came here and promised us that he will see to it that all of us have proper homes, in truth all of us are poor people and not holding proper jobs or anything so it's understandable. Some people know to make some effort to get what they want, some people just don't know how to. I am one of these that know how to get what they want. So I started getting my house. Four years ago, in 1999, I started this house.

BONACCI: Do you have proper papers that this plot of land belongs to you?

JUNIOR DAN: None of us have proper papers regarding land titles. Land grant was given to us and we are recognized here by the government that we are settlers from Jamaica and we do everything official through community, and we have a chairman of the community body, a executive body and they look after all official business. This particular house including all the houses that we built on the land is processed through the government, Nazret [capital city of Oromyia region] and Addis Ababa and the Shashemene meker bet. Now all these things are being processed. Especially since they destroyed my house, the process step up. Myself have an appointment to see the people that demolished that part of the house. Maybe in this coming week.

BONACCI: Is one of the arguments that you don't have a master plan? 
JUNIOR DAN: Yeah, argument is that we don't have no master plan, no plan at all. Although I don't have official title I have plan fe me house. Everyone knows, it's not a secret. Why the house was never finished before is because I had two operations in the midst of that four years. Last August and three years before that. That's the reason why my house is not finished. I was doing everything, financing and doing the work. The last operation I went to Addis Ababa.

BONACCI: How do you think this place will move forward?

JUNIOR DAN: We need to have government in Addis Ababa that is dealing with us, recognize us, just not as people who come from foreign and leave here, but recognize us, as we are. We claim Ethiopian nationality. We don't believe we know that we are Ethiopians because of our genealogy and our history and that is why we are here. One of the ways is if we have the monarchy running the government in Addis Ababa. Another way that will be better for everybody: if you have a government that is not dividing and ruling the people but keeping the people as His Majesty had them before, everything will go more progressively.

BONACCI: Such a political position couldn't work against the community?

JUNIOR DAN: It wouldn't work against the community because the community representing the monarchy. The majority of the people in the community represent the monarchy. So if monarchy is there, it couldn't be political for the people who is there. Government there is anti-monarchy. We any time we could get ourself in really political lobby with these people because they see us anti with them but we're not dealing with them or their policies. Except that now we have some agreement and try to draw the line with them. But their policies we' re not dealing with that at all. And they know that. We barely tolerating each other, not recognizing each other fully, because otherwise we would have opportunity, like people coming through immigration and customs would have better reception. We are not having proper response from each other. When we really get a headway here and progress is when we have the monarchy or different political system.

BONACCI: The move of Immigration to register the people is not positive? ${ }^{19}$

JUNIOR DAN: It is positive but so slow, and is still hampering the growth and development of the people that were born in this country. They don't have proper identification, no credential. Even authorities are still reluctant to deal with our case here. Those are the progress I look for immediately, among other, we need proper development, community centers, like medical places, give thanks we have a school but we need to build it more. But the system have to change, especially for the Rasta community, no way they accept us as we is. They claim they accept us but I still see the prospective of it. 


\section{NOTES}

1. The Christian name of Junior Dan is Norval Sylvester Marshall Junior. He kept the name "Junior," given to him by his father, and Dan is his Rastafari name, as he is a member of the Twelve Tribes of Israel and identifies with the tribe of Dan.

2. See the second edition of my book on the social history of African American and Caribbean repatriation to Ethiopia since the nineteenth century, with a particular focus on the Shashemene settlement.

3. St. Andrews and Trench Town are downtown areas of the capital city Kingston, inhabited mainly by lower middle class and working poor Jamaicans.

4. The Twelve Tribes of Israel were founded in 1968, but the organization was already functioning as chapter fifteen of the EWF.

5. Chevannes has underlined the importance of dreams and visions in the life of the Jamaican people and particularly in the process of converting to the Rastafari faith. See Chevannes 110-14.

6. Junior Dan is making reference to the Ethiopian Christian Orthodox fasting, usually held on Wednesdays and Fridays.

7. Two Back-to-Africa missions left Jamaica, in 1961 and in 1963. Delegates of the first mission visited five African countries (Ethiopia, Nigeria, Ghana, Liberia, and Sierra Leone) in order to study the possibility of Jamaican migration to Africa. An unofficial second mission, organized by three Rastafarians, went to Nigeria, Kenya, and Ethiopia.

8. Filmore Alvaranga, Douglas Mack, and Mortimo Planno were the three Rastafarians participating in the official 1961 Back-to-Africa mission set up by the Jamaican Government.

9. Vernon Carrington, also known as «Prophet Gad,» was the founder and leader of the Twelve Tribes of Israel.

10. Until 1968, the congregation gathered by «Prophet Gad» was functioning as chapter fifteen of the EWF. In what can be understood as a schism from the EWF, the Twelve Tribes of Israel were officially founded in 1968.

11. After the revolution and the land reforms of March 1975, many among the two dozens of Rastafarians living on the land grant in the periphery of Shashemene left the country. Afraid for their life in the midst of major social changes, they preferred to go back to the United States or to Jamaica. A few remained in Ethiopia. Of those who left, only one woman came back to Shashemene, in 1995.

12. The executive body of the Twelve Tribes of Israel is formed of two benches of twelve bredrens and sistrens representing the twelve tribes of Israel, and one sister who represents Dinah, Jacob's daughter.

13. This anecdote shows how close certain members of the Twelve Tribes of Israel were to the Jamaican political circles. It is one of the characteristics of the Twelve Tribes to have widened the Rastafari movement to middle and upper classes. See van Dijk.

14. The Twelve Tribes of Israel were known for their dances and their active support of reggae music. The organization was sometimes called the «house of reggae.» See Hepner 144.

15. Junior Dan specifies «old settlement» to distinguish clearly from the 2003 settlement. The old settlement was bordered by a field where young people used to play football, and it was situated at about two kilometers from the town of Shashemene. These two kilometers were then mostly small parcels devoted to agriculture as well as grazing lands. See the map of the settlement in 1975 in Bonacci 369.

16. Even though the Oromo language is widely spoken in the Shashemene region, Amharic was and still is a common language.

17. See the map of the 1986 distribution of eighteen lots of land in Bonacci 390.

18. After the fall of the Derg in 1991, a new Constitution was adopted in 1994, and came into force in 1995. It provided for a federal government of nine ethnic-based regions. See Vaughan 27-39.

19. In February 2003, a census was conducted in the Rastafarian community.

\section{WORKS CITED}

Bonacci, Giulia. Exodus! L'histoire du retour des Rastafariens en Ethiopie. Paris: L'Harmattan, 2010.

Chevannes, Barry. Rastafari, Roots and Ideology. Syracuse, NY: Syracuse UP, 1994.

Hepner, Randal. "Movement of Jah People": Race, Class and Religion among the Rastafari of Jamaica and New York City. Diss. New School for Social Research, New York, 1998.

van Dijk., Frank Jan. "The Twelve Tribes of Israel. Rasta and the Middle-Class." New West Indian Guide 62.1-2 (1988): 1-26.

Vaughan, Sarah. Ethnicity and Power in Ethiopia. Diss. University of Edinburgh, 2003. 